\title{
Progress bases: biology and cognition
}

\begin{abstract}
The survey deals with civilisation upshots, tackled through 〈biology〉 and 〈cognition〉 paths. 'Growth〉 entails life-quality rise. It ensues by linking previous and latter situations, by relative appraisals, as if absolute references exist. The accounts, actually, establish, using our beliefs in «natural laws), taken as (cosmos inborn or God fixed) truths. This is haughty approach, epitomised by easy trusts (see «the theory of everything), which unify our models, as if coherent causative patterns are established. With genome decoding, the molecular biology expects simplifying former patterns by covering the cognition outcomes. In this study, we move around these topics, suggesting that haughty truths shall need revision, when just grounded on a priori faiths. The thrift alternative accepts 〈life〉 and 〈intelligence〉 singularities, and replaces absolute by contingent conclusions. The progress becomes man-driven effect, by gene evolution (backed by biology) and meme fruition (backed by cognition). The construal builds around the 〈relational men's gifts, offering operational insight on artificial intelligence prospects.
\end{abstract}

Volume 4 Issue 6 - 2018

\author{
Rinaldo C Michelini Di San Martino \\ DIMEC-University of Genova, Italy
}

Correspondence: Rinaldo C Michelini Di San Martino, DIMEC-University of Genova, viale Francesco Gambaro 6-16I46 GENOVA-Italy, Email michalini@dimec.unige.it

Received: September 13,2018 | Published: November 16, 2018

\section{Introduction}

The human sceneries characterise by the culture and ethics artefacts, which add to the earth habitats in the background and allow crafting the 〈civilisation». The 〈progress〉 opposes to 〈wilderness〉 by the synthetic formation of men's alterations of the intrinsic cosmological frameworks. The changes or adjustments in the inborn 〈regularity〉 (or «stability), stated by posited (natural laws〉) are mostly tiny details, on earth and into man's access. It is hard asserting that the universe could improve or worsen this way. If «natural laws〉 exist at global range, surely, the human «civilisation〉 reach negligibly affects the extant trends. The narration of the «civilisation can be done, assuming that the cosmos' backdrop remains totally impervious. ${ }^{1-4}$

The earth habitats undergo purposeful alterations, because selfacting items start locally running, with automatic duplication and proliferation, and logical construal operations start being staged for choice-and-job-enabling. The occurrences describe by «singularities〉, namely:

a. The 〈life: agentive process, rooted in gene evolution, towards adaptive propagation;

b. The intelligences: rational way by meme fruition, to aware decision and action plans.

The «singularities〉 permit distinguishing front-end limited peculiarities, from the general backdrop; if the latter is ruled by «natural laws>, the earth resident biology and cognitive trends might follow via alternative readings, say: 〈monism», immanence in the overall cosmic actuality; 〈dualism), carried by a transcendent or a mimicry received actuality. The upper or the gained realities diverge from the cosmos' tangibles, because they classify as intangibles, at least, when their shaping moods are involved. With 〈monism〉, 〈matter〉 and 〈information〉 merge; with 〈dualism〉, they differ, as 〈programmes〉 act on the 〈stuff), by (processing parts〉 and 〈operation systems〉; so, the reality entails (matter〉 and 〈spirit), i.e., by transcendence, deity and soul, or, by mimicry gains, feel and makeup. In men, the 〈spirit» well identifies by mind separation from brain. In «monism», such parting does not exist: aura and life-force are just given names, as 〈spirit〉 is 〈stuff-inborn〉. The tangibles/intangibles 〈dualism〉 is postulation explored to free the information> from the «matter», so to distinguish potential decision logics, for modifying the event course, out of the strict determinism. . $^{5-9}$

\section{Basic mankind peculiarities}

The earth backdrop authorises looking, without marvel, at current peculiarities: biology and cognizance are obvious, once supposing the multiplicity of committed actors and discerning performers. The universe without aware players seems to us useless, and we cannot conceive its coherent foundation (Figure 1), even if exclusions and substitutions have conscious acceptation. ${ }^{10-14}$

The «natural law role is left unspoken. Nonetheless, the belief to deal with inborn linking constraints or upper assigned controls is easily understood, bringing to the absolute immanence or transcendence of the tied worth. When the silent guess is removed, the contingency value of the framework is evident: the rules are stated after shared men's choices, timely weighted along with the (falsification principle〉; the cosmos' order coherence has interpersonal basis (Figure 2), with theoretical appeal due to the enacting scientific group. The 〈dualism〉 is received or operation outcome, built to discern the intangible valueadded assets. ${ }^{15-18}$

The cosmos' order has apparent trustfulness, when described by «natural laws〉 with absolute worth. The received dualism establishes on 〈relational modes〉, i.e., on the sets of culture/ethics artefacts accredited to characterise the given civilised community (Figure 3). Only men, among the animals, can be: coached to possess idioms, prepared to profit by bargains and businesses and advised to conceive governance authenticity. The setups, thereafter, are stated as a posteriori 〈rational〉 choice, not possessing a priori worth. ${ }^{19-24}$

The relational options, language, trade and legality, are men's invention, based on interactive learning and modelling of the community advantages. The achievements are developed, via education and mimicry, adapting and improving communication, 
dealings and governance. The instigation of relational chances has total incorporeal roots. The role of intangibles in the ccivilisation> build-up is decisive; moreover, the extant analysis shows that the (progress is joint outcome: it cannot link to the single; it requires the cooperation of specified assemblies, under conscious, regulated and (possibly) official connections.

The contingent (in lieu of absolute) trust in the sprogress>, ineludibly, links with our limited access to the «cosmic truths», 〈matter〉 and 〈information〉 and allied «natural laws〉, if any. It connects, moreover, with the ambiguities of the scale effects between our hangouts and the entire universe (Figure 4). The absolute readings entail entropy trends; our retreats' ecology is further damaged by depletion and pollution queries. ${ }^{25-29}$

The interactive concern of collectives is extra peculiar requirement. We distinguish two options:

a. Open unions: the groupings operate on people because of shared goals and pursuits; b. Closed unions: the enclaves entail people belonging to pre-set official organisations.

Friendship and fellowship are first option examples; in the mankind, the communication readily creates languages: diction and parsing rise barriers. Market and craft are men's ingenuities at ajar range; shop and skill segregate the professional abilities. Only right and sovereignty are second option examples, if bottom-up man statements; they may be thought spreading the universe over, if absolute truth. We have the final result that the contingency assembling aims at closed unions, notably, on governance targets, and, as well, on communication and business marks. The relational links, in conclusion, can follow alternative ways: the altruism with «open union〉 forecasts, to hand-on intents and benefits, the world over; the solidarity wit 〈closed union〉 prospects, to grant support and protection of the clan's members. The 〈relational〉 gifts of men are essential peculiarity, not shared with the other living beings. The listed plus-values (Figure 3), typify situations in communication, business or sovereignty not at all conceivable if the cosmos' backdrop is only available, to organise the personal or communal behaviours of individuals and communities..$^{30-36}$

MATTER $v S$. INFORMATION: THE EXISTANCE OF UNIVERSE'S GOVERNING CODES:

THE ORIGIN AND EXAUSTIVE INSTITUTION OF THE (NATURAL LAWS) (IF ANY)

THE ALLEGED EXCLUSIONS (SINGULARITIES, MIRACLES) TO (NATURAL LAWS)

THE EXISTENCE OF MODIFIED, REFORMED OR ALTERNATIVE (NATURAL LAWS)

Figure 1 The coherentfoundation of the cosmos' order.

\section{RECEIVED DUALISM: LIFE AND INTELLIGENCE SINGULARITIES HAPPEN ON EARTH \\ THE LIFE ENABLES AGENTIVE PROCESSES, LETTING SELF-REPRODUCTION ISSUES \\ THE INTELLIGENCE ADDS RATIONAL STEERING, ADDRESSING TO IMPROVEMENTS \\ THE RELATIONAL CONTEXTS ALLOW AWARE CHOICES BY DECISION-KEEPING CAPACITIES}

Figure 2 The contingencybasis of mimicrygainedsetups.

$$
\begin{aligned}
& \text { COMMUNALASSEMBLIES, WHICH ENHANCE THE PERSONALFELLOWSHIPCONFIDENCE } \\
& \text { LANGUAGECOMMUNICATION, WITH VOICEAND GRAPHIC CODING AND GRAMMARTIES } \\
& \text { FIRMBUILD-UPS, WHICH AIM AT THE COMMERCIAL RUNNING OF BUSINESS PROJECTS } \\
& \text { TRADE CONNECTIONS, WITH MARKET RULES, CURRENCY BITS AND CRAFTY TRANSACTIONS } \\
& \text { LEGALITYSETTINGS, WHICH ALLOCATE FIT SOVEREIGN SELF-RELIANCE TO GOVERNMENTS } \\
& \text { LAWAUTHENTICITY, WITH BACKING ASCENDANCY AND OFFICIALDOM EXECUTIVE GEARS }
\end{aligned}
$$

Figure 3 The relationalplus-valuebyvoluntary/controlled catches.

UNIVERSE VS. EARTH, NOT AKIN REALITIES: THE LATTER IS NEGLIGIBLE COMPARED TO THE FORMER

EARTH: OVER-DEPLETION/POLLUTION BRINGS TO (PROGRESS) END, BY PENDING SCARCITY/LITTER

UNIVERSE: ENTROPY IS LONG-TERM PHENOMENA, YIELDING DECAY AND DEFEATING HABITABILITY SUSTAINABLE GROWTH: EARTH PROVISIONAL RECOVERY BY (TO DEMATERIALISE)/ (TO REMATERIALISE)

Figure 4 Questioned 〈progress〉, on universe's bases. 


\section{Life and intelligence wonders}

The cosmology may, possibly, resort to the «natural laws», if absolute <information〉 consent running the extant 〈universe〉. Einstein prospected using the space-time 4D reference, to describe the astral dynamics. Lately, force fields unification (Figure 5), suggested widening to the Kaluza-Klein 10D reference, to include all the presently modelled physical interactions. The 3D geometry is needed: lower dimension cannot consent stable orbits, under central forces. Kaluza found that the general relativity equations, written in $5 \mathrm{D}$, require a further condition: the electro-magnetism. The 10D extension is subsequent model, with the string's guess to smooth away gravity inconsistencies. The 1D time is interpreted bending the geometry; the 6D (hidden) dimensions are out of any visual restitutions, when performed, just, using polar lines-of-sight. ${ }^{37-41}$

The relativity is turning point: we start grasping that the physical surrounds is hardly what perceived via optical snap-shots: series of these document the backdrop twisting, under matter-energy coupling. The 3D geometry is due to the human spot restitution: it is not absolute truth. The 10D broadening is hunted guess at the extant scientific practises. This way, cosmology well integrates in our developed physics by coherent models. Turning the view on the earth, the biology and cognitive events are potential further widening, to be joined, once common traits are gauged. The contingency description is free from unifying consistence: it resorts to spot restitutions, and accepts partial accounts, without general impact. Aiming at our know-how, the life and the intelligence wonders are unusual cosmos' options, promoting odd new upshots, such as:

a. An agentive trail, e.g.: gene evolution, solidarity, ethnic greediness, selfishness;

b. A rational trail, e.g.: meme fruition, altruism, conscious humanity, philanthropy.

The automatic causative happening of facts, with deterministic continuation of the cosmic starkness, is replaced by the relational furtherance of acts, via gene evolution or meme fruition changeovers. The cause-effect plainness is forgot, avoiding pre-determined schemes. Yet, how men reach pertinent 〈information`? Our knowledge does not enjoy actual worth; we cannot prove understanding the cosmos laws. The inferred models prove by the (falsification principle) and are used in that contexts (Figure 6); for instance, the genome decoding is thought offering hints on the information/matter links, and, perhaps, between (genetics〉 and 〈wisdom〉, devising the latter as 〈awarenessplus-spirituality> mix. ${ }^{42-46}$

The mechanicalness is curious faith in (immanent or transcendent) 〈natural laws»: it leads to assume the automatic reprise of a priori logics in the life and the intelligence processes. With the smolecular biology, a similar track applies to invent genome-driven logical mechanisms (Figure 7), as the 〈spirit〉 identifies by 〈aura or strength〉. The force-fields unification is read as 〈theory of everything》. The contingency appeal is demoted; the life/intelligence novelty is jeopardized. The priory automatism logics are agreed belief. The existence of «conscious actors〉 is noticeably unjustified event, looking at the surrounding universe, as deterministic structure, carrying inert objects and causative processes. The genome reductionism, if the practises verify and fit laboratory procedures can be checked, is appealing option, suggesting a sort of 〈biology of the spirit〉 hypothesis, totally written in the genome and/or in extra databases under way discovered. ${ }^{47-50}$
To look at the guess, some cues follow. The living entity defines to be: ‘organised material piece, having time and space limits, capable to metabolise, reproduce and renovates. By the root, organ on directly links to procedures involving the life forms: spanning and spotting bounds prove to deal with met stable interim pieces. The listed knacks show the request of programme, processor and operation system. To be alive, the organic bit shall handle matter and information, suitably updating the carrying body. The genome decoding clarifies the programme; the cell behaviours portray the processing sequels: self-reproduction is essential feature; a virus is just genome requiring a satellite cell, to replicate: as such, it is not a living being. In the definition, the resort to a cell is omitted: the cell-less life is oddity. In any case, the programme alone is not the life we know (being the genome, just, a programme). With no process automatism, the <biology of the matter is defective; we need further cues. The parallel of 〈biology > with 〈cognition〉 may help, taking two processes, the one for gene evolution, the other for meme fruition. Both imply operation system matches; the second may address conscious actors (Figure 8), once the change means avoiding a priori organisation, just, replaced by the a posterior check of the upshots: whether still in-progress or stopped. $^{51-55}$

What sketched by the Figure 6, Figure $7 \&$ Figure 8 shows the approach similarity to append the earth episodes to the cosmos' model, purposely referred to a more or less a priori defined «theory of everything), namely:

a. The mechanicalness of the background, notably, inspired to forcefield unification;

b. The operation goings-on, based on the genome-goaded organismal achievements;

c. The route completion, by automatic pre-setting, either, by mimicry gained options.

Initially (Figure 6), the procedure is stated; the mechanicalness brings in the odd faith, to merge programme, processor and operation system. The possibility of the event (Figure 7), could make believable a thorny biology as if the cognizance would have the genome driver. The conviction is twofold faulty: the faith in the quoted merging cannot avail of a priori surmises; the result is possibly detected, only, by a posterior checks, once cognition occurred; so (Figure 8), at the state of the science, we address to pertinent «singularities), switching off the faith in unrealistic automatisms (the faith in 〈singularities〉 has plausible signs!).

The received dualism does not assume axiomatic backing (not proved). In lieu of (truth〉, (contingency) is reached, besides, establishing additions at the intangible synthetic by-product range. A plain cue reveals it: the «mind ripens by (communication», i.e., interpersonal formats. The conceived pieces of knowledge and agreed behaviours are intangible crafts, at provisional worth, varying on the shared span. Due to dualism, anyway, the mind sphere is free from deterministic cogency, because pertaining to abstract domains, not «matter〉 embedded, but expressed after interactive bargain, if intelligence is accepted singularity. This way, the mind/spirit worlds develop by meme courses: they follow clashing tracks, which add to the gene ones. That dualism presumes distinct paths: in the matter one, through which the 〈surround fitness plays central roles; in the intellect the other, at meme deployments. Moreover, both are contingency upshots, more than (upper driven or inborn deterministic) absolute outcomes. Definitely: the adaptive fitness operates as the 
issue of genome alterations, ending in modified offspring, in which fitting specimens have bigger chance to survive and to proliferate. The «natural selection» is typical contingency result: it addresses new met stable outfits, ex tempore obtained by gene variations, in the average, yielding to adapted progeny. In parallel, the enhanced talent clans distinguish by relational effectiveness, after mimicry contest and step-up opting. The meme course is totally occurring at the intangible level; it is alternative to the transcendental driving and in contrast with the deterministic setting. But, the received dualism expressly goes this way. ${ }^{56-61}$

\section{THE FORCE FIELDS UNIFICATION BY STRING (VIBRATING DOT) DEPICTION RELATIVITY DYNAMICS: 4D REFERENCE, 3D SPACE PLUS 1D (IMAGINARY) TIME ELECTROMAGNETISM: 5D REFERENCE (WITH THE FITH KALUZA-COORDINATE) WEAK/STRONG NUCLEAR FIELDS + GRAVITY: 10D (WITH STRING REPLACING)}

Figure $\mathbf{5}$ The reference framework for unified force setup.

THE ALTERATION PROSPECTS EXPERIENCED BY THE HUMAN SCIENTIFIC GUESSES
MECHANICALNESS: CAUSE-EFFECT PATTERNS, DESCRIBED BY PRE-EXISTING FRAMES
GENE EVOLUTION: ADAPTIVE PATTERNS, WITH DECISIVE SURROUNDINGS' STEERING
MEME FRUITION: CREATIVE PATTERNS, WITH COHERENT MIMICRY GUIDING CHOICES

Figure $\mathbf{6}$ The reference hypotheses for the contexts' changes.

THE `MOLECULAR BIOLOGY ' GUESS OF LIFE-FORMS' MATTER/SPIRIT ORDERS
BIOLOGY OF THE MATTER: LIFE BEGINS THROUGH ORGANISMAL GROWTH AND LIFECYCLE ITERATION
BIOLOGY OF THE SPIRIT: INTELLIGENCE STARTS OWING TO AWARENESS AND DECISION CINSISTENCY
THE CONSCIOUSNESS CREATION IS RESTRAINED TO MATTER/ENERGY INTRINSEC AUTOMATISMS

Figure 7 The hypothetical course via determinism logics.

\section{THE «RECEIVED DUALISM) GUESS OF LIFE-AND-INTELLIGENCE SINGULARITIES BIOLOGY: GENE EVOLUTION, ORGANISMAL PROCESSES, LIFECYCLE ITERATION AND PROLIFERATION COGNITION: MEME FRUITION, RLATIONAL MIMICRY CHOICES, COGENT AND RATIONAL CONSTRUAL THE CONSCIOUSNESS CREATION IS IS EXCPLICIT OF SPIRIT (FEEL AND MAKEUP) MIND CONSTRUAL}

Figure 8 The prospected course with cognition chances.

\section{The contingency innivation establishment}

The 〈relational talent develops at the mutual range. In the drawn scheme, meme fruition follows gene evolution, once the human babies are trained to fulfil basic acts by language, trade, legality, etc. tools. The communal spheres are obviously limited at the parental, clan, town, nation, etc. spans, but the reaches are factual upshots, with abstract weight, at intangible range. The scale factors play biasing effects, maybe, by shaping the minds: e.g., the political scope exploits country's patriotism, to establish inner glue vs. external rampart. In principle, the posterior contingency, today, fully replaces the a priori absolutism (Figure 9). Yet, in the previous survey, the mechanicalness is strong inspiration to deal with automatisms (Figure 7), tightly linked to pre-set frameworks. We shall reconsider the basic details on recurrent stirring blunders. ${ }^{62-67}$
The mechanicalness, above linked to natural trails, dictates in technical domains, by the earthly world's reductionism methodologies. The organism course is old picture, successfully replaced by the molecular biology, notably, dealing with natural «life. The 〈biology of the spirit» is engaged at looking if the child's brain has modified architecture, predisposed towards learning and training, with language, trade, etc. bent. The natural «life», perhaps, cannot be exactly gained by the cosmos' laws (with unified frames (Figure 5). The natural (intelligence〉 of the cognition trails (Figure 10), has, generally, to explain how the relational talents are started and the linked shared intangibles are implemented just in men (not in chimpanzees). ${ }^{68-72}$

We expect that the 〈molecular biology will provide the many details telling 〈brain〉 and 〈brain coupling〉 statuses and functions, to understand the tied relational options, describing the 〈mind». The 
«biology of the spirit, by now, is equivocal saying, better grasped using 〈cognition〉. The seizing, thought, reasoning, etc., in fact, generate, after perception, series of intangibles, which describe as (intelligence) functions and identify as «spirit) talents or «mind) qualities. The confusion spreads over, when the «spirit» is thought the existence essence, i.e., (transcendent) deity and soul or (immanent) genomics and life-force or (contingent) state and individuality. When it is impossible proving the actuality of the hypothesized outlines, the linked definitions of 〈spirit〉 are just faiths (maybe, agreed as absolute truths); the puzzlement only lowers, when we accept a posterior statuses and situations, as received conjectures, with provisional worth. The bottom-up track, by now, with poor 〈brain〉 and 〈brain coupling), looks at post-born teaching/training and at oriented education with the relational interaction, creating intangible databases of procedures with qualifying applications.

At the moment, 〈biology〉 and 〈cognition〉 do not merge; the 〈spirit〉, at the received duality range, deals with intangible supplements, basically, conditional build-ups and personal identifications, to extract actors with awareness, intellect and rationality. The meaning of the incorporeal supplements is left to a posteriori assessments; yet, the «spirit) deeply modifies the earth's scenarios, by the cognition aid (Figure 11), because:

a. The spirituality is deemed enabling the culture/ethics intangible fall-outs;

b. The spirituality confers abstract substantiation/furtherance to civilisation.

Today, face to the global ecology perils, the question «can spirituality safe the civilisation?> is posed, to contrast the <biology of the spirit>, the awkward track, hinted after the genome reading, as absolute truth. The 〈biology labels the steps bringing to generate self-reproduction entities, from the synthesis of peculiar amino-acids, through joining of DNA-like suites and cell organisation singling out. The <cognition> tags are used to specify the relational virtues, created by men, from the children tutoring, to the home-and-market running and to the governance fashioning. 〈Intelligence〉 is not aftereffect of 〈life〉. The rational orderliness follows methodology (rather than ontology) departure from entropy trends: occurrences, such as 〈life〉 or «intelligence〉 are singularities (not needing proofs), followed by genomic and relational upshots; processes, such as the recalled, widen the 〈actuality> by intangibles, promoting agentive and rational issues. $^{73-77}$

The analyses limit to list observed steps: these are aftermaths told, having gene root by fitness context or meme basis by coherence glue. The steps have: an origin, whose plausibility is accepted because facts follow; and because proofs are disguised at cogent inner logic, yielding non-anticipatory/contributory plots. That way, the 〈knowledge〉 establish, encompassing the 〈science〉 and 〈know-how〉, being needless telling the underpinning origin and logic. The portrayal is understood ensuring ontology worth, accepting haughty truths and neglecting thrifty opportunities. Physics has self-reliant ontology rituals; the unified fields (Figure 5), are «theory of everything result. The mind reduction to brain, maybe, unifies biology and cognition; but it does not imply the unification of the 〈cosmos' laws〉. If 〈matter〉 and information〉 have a priori setups, the all is out of men's reach. The men's «knowledge is contingency outcome (Figure 12), put up on perceptions and models, and imagined holding figures, principles, theories or formulas, valid as 〈cosmos' information». The tied ontology is, hence, debased: reductionism is practice, with no claim of objective truths of the ends.

RELIANCE IN ABSOLUTEE PRINCPLES: REALITY HAS SUITABLY ACCESSED A PRIORI PRE-SET MODELS

TRANSCENDENCE: GOD ROUTING BY TRUTHS - IMMANENCE: DETERMININIST FINAL OUTCOMES RESORT TO CONTINGENT PRINCIPLES: THE MODELS ARE A POSTERIORI MIND INTERPRETATIONS

TANGIBLE AIDS: TECHNOLOGY REVOLUTIONS - INTANTANGIBLE AIDS: SOCIAL BREAKTHROUGHS

Figure 9 The switch, from absolute, to contingent grounds.

\section{THE (MOLECULAR BIOLOGY) GUIDANCE OF LIFE-AND-INTELLIGENCE INQUIRIES BIOLOGY: DIRECT GENOME EFFECTS ON THE BRAIN DEVELOPMENT AND FUNCTIONSL OPERATIONS COGNITION: BRAIN INTERACTION SCHEDULES AND RELATIONAL MODELLING OF DEEDS AND MAPS THE CREATION OF THE MIND NEEDS MUTUAL PROGRAMME AND BRAIN-SHARED OPERATION SYSTEM}

Figure 10 The biology assistance of the cognition tasks.

The all may be metaphors, which help displaying how we deal with views (on earth, universe, etc.), and how we interact with what discerned, monitored and witnessed: notions or allegories shall not be mistook as truths. Science is engaged by those hitches. In cosmology, the big bang with ensuing inflation/expansion is emblematic instance; quantum mechanics unified field, by multiple-space string tales, is example picture, at mathematical range. The brain/mind mix-up is 〈biology〉 account, if monism prevents extricating matter from information. The confusion assumes programmes in the carrying stuffs, and suiting has intrinsic inner cause: i.e., the genome is agenda, entailing operation system and processor, with no need of programmer: it is gifted by suited doling out feasible plans and 
practices. The disposition replicates at meme stage, after the gene one; the men spirit is deterministic internal representation of detached truths, not changeable, as coming out from intrinsic directories. The interpretation reflects persistent incomplete ability to appreciate the (intelligence) as the enabler of relational modes, with intentional social fallouts. ${ }^{78-82}$

The dualism is alternative to monism. It assumes autonomy of matter and information, as if a self-reliant abstraction applies, to preside over intangibles. Transcendence opposes to immanence; the godlike sphere includes a 〈designer), out of the material one. The divinity is inspired absolute representation of detached truths, not changeable, since coming out from God directories. The resort to an upper world, out of men's universe, requires the 〈faith〉 in the existence of the heavenly reality, since, being out of material views, we cannot experiment on it. The guesses of the God-driven dualism are echoed by the men's religions, which developed on earth, to assign the categorical imperatives to the invented socio-political «collective orders .

The situation is not markedly different from the monism 〈faith〉, when 〈absolute readings apply to the molecular biology outcomes: the ontology construal of the sbiology of the spirit claims scientific strictness to gene path to include meme basis, leading to agentive and rational orderliness. The listed facts provide allegories, devoid of conclusive worth. Yet, the dualism and monism 〈faiths〉 enjoy the advantage of yielding (absolute) appraisals. The result entails resorting to heavenly or intrinsic truths: these are driven by rules, already coded as godly or inborn 〈laws〉. Their authenticity is simple, if the all sticks together, but the men have preordained fate, at the mercy of divine will or fixed by deterministic a priori path. The 〈biology and 〈cognition〉 merging has the conflict of the 〈faith〉 reading, and the drawback of the pre-set ends.

\section{THE (AWARENESS), (INTELLECT) AND (RATIONALITY) COLLECTVE DEPLOYMENTS \\ FACTS: THE PROCESSING OF INTANGIBLES, TO GENERATE CULTURE AND ETHICS ARTEFACTS \\ REWARDS: THE APPRAISAL OF PROFITS/DRAWBACS OF DIFFERENT INTERTACTION POLICIES \\ TENETS: THE COMMUNITY ORGANISATION, WITH ENACTED REGULATIONS/PUNISSHEMENTS}

Figure I I The cognition aid to spiritual values and civil rules.

\section{THE (CONTINGENCY) IMPORT OF THE INTANGIBLES BY THE (RECEIVED DUALISM) \\ CULTURE: THE UPSHOT OF SHARING MODELS, FOR DECRIBING THE UNIVERSE WITH LINKED LAWS \\ ETHICS: THE SYNTHESIS OF ALLOCATED PRINCPLES AND TENETS, FOR THE COMMUNAL COHESION (knowledge): DATA PROCESSED BY FALSIFATION PRINCPLE, TURNED IN CREATIVE (information)}

Figure 12 The «knowledge inferred as creative sinformation〉.

With the received dualism, the «spirit〉 does not identify in deity and soul; it is accepted as posterior conditional statuses and identified individuals, resorting to contingency conjectures, based on a posterior assessments. The readings require affixing the hypothesis that, both, the 〈life〉 and the 〈intelligence〉 start from singular points, and that the subsequent gene and meme processes are autonomous fallouts (we do not have proofs of links). The molecular biology just affects the «life) singularity course. The intelligence portrays by its relational qualities: the rationality tracks culture and ethics steps, due to interactive setups, managed via teaching and training. The human baby can be educated and focused, with language and trade skills. Until today, no gorilla baby could be turned in novelist or merchant, even if the genomes are almost the same than in man. The 〈dualism ' has operation virtue: tangibles distinguish from intangibles. The meme fruition produces incorporeal culture/ethics artefacts (not divine beings). The relational courses form minds (not godlike entities). The knowledge (maybe, identified as created (information〉) does not exist before, so it is possible crafting the civilisation plus-value, and discovering timely new processes for its continuation.

Contingency is conditioned, not pre-set. By absolute readings, 〈information〉 is meant chasing two paths: self-reliant design backdrop; on-progress man's knowledge. The universe shall already contain the controls that make likely the later occurrences (life and intelligence included). The absolute readings are undecided. The man's knowledge, perhaps, brings about creative information, with endlessly increasing data. In lieu of fated destiny, the received dualism interacts with nonstop expanded know-how, making interplay feasible towards men minds, which are spirituality driven, into the discussed frames. Hints are recalled. The social responsibility requires that: the humans are observers/actors, endowed of rational understanding and free will; the surroundings allow feasible choices, comprising the ones towards reliable progress. Only in such conditions, we can say that the man is author of his fortune or misfortune. By contingency, the fortune or misfortune is deferred to a posterior assessments. However, the «relational intelligence implies modelling and planning capabilities; the linked attainments are social responsibility of the extant world's populations. Presently, the ecology globalisation tells us that we are citizens of a unique global village, not leaving out resorts into castling; the eco-sustainable choice cannot authorise different behaviour unless the <altruism), because the «mors tua, vita mea> does not offers benefits. ${ }^{83-86}$

\section{Conclusion}

The 〈progress is awkward man's stipulation, which assigns lifequality labels and gauges the 〈accruals〉 or «wealth expansion〉 against 
the 〈losses〉 or 〈tenure decay〉. The 〈progress is surely not cosmos' condition. In its case, the linked (matter) and information〉 appraisals consider deterministic trends, properly described by the «natural laws〉, and, typically, affected by (entropy> rotting. Besides, the sprogress> is acknowledged as aware growth. The (growth〉 characterises 〈life〉 and 〈lifecycle», i.e., the headway of individual beings and their proliferation ability. On the earth, the man is further oddity, displaying his (intelligence), which yields cognizance and judgment: the rational reasoning justifies the feeling about the life-quality enhancement, or the choice between 〈accruals〉 vs. 〈losses〉. The 〈progress〉 does not precisely entails the universe and linked natural laws; it certainly involves the 〈biology incidents. But universe vs. earth is unequal pick, even if, in principle, a single set of «natural laws〉 is dealt with. ${ }^{87-91}$

Moreover, for long time, the faith in transcendence allowed resorting to God's favours and gifts, which entailed the life and intelligence origins. The godlike spheres are not attained from our material surrounds, and the hypothesis is just faith, directly colliding with our scientific beliefs. After Darwin, the evolutionism is thought prospecting expansion of the living worlds, even with social effects. The genome decoding specifies the life programme; we see that «matter〉 contains 〈information〉, to be made operative. Faith suggests the 〈biology of the spirit), as the «spirit〉 is thought the essence of the reality, maybe, a priori extant «deity and soul〉 or «strength and might), or a posterior identified «condition and personality). Still, overconfidence in plain 〈hoc post hoc〉 added with «ergo propter hoc) does not allot better reliability to immanence compared to transcendence: both keep absolute mark, but the thrifty contingency reading enjoys higher consistency if just a posterior guesses are accessed. On these premises, typical queries follow, such as:

a. Does the cosmos' (information〉 deliver to men absolute accounts via «natural laws`?

b. Does the cosmos' 〈information〉 entail the paired 〈biology〉 and 〈cognition〉 processes?

c. Does the human knowledge reflect the cosmos' 'information〉, at least, approximately?

d. Is the human knowledge effective, even if the cosmos' information is never accessed?

e. Do the 〈biology and «cognition〉 processes specify independent or complementary data?

The answers are outlined in the study, and shall not be retold. Further remarks deals with the relational modes, distinguishing the men, from the other living beings, say: mutual communication, creating idioms; trade, inventing market and money; governance, stating sovereignty and legality. Complexity, concept and construct of what devised appear out of the cosmos' backdrop. The rules for idiomatic words, grammar and syntax, the business of balancing requests-to-offers, the rubrics for authority and laws may be obvious acts, but a priori frames lack. When a posterior tracks are hunted, mimicry and emulation fast help copying and spreading the fallouts anywhere, up-dating or replacing the earlier practices. Yet, the all splits the haughty visions of who has faith in absolute truths, from the thrifty attitude of who accepts provisional guesses.
The concepts of «natural laws〉, «causal frames〉, 〈total trusts〉, etc. are haughty side of the science, fully removed switching to the «contingency) of relational agreements between a given subset of animals. In the study, we may look at dividing the justifying guesses with two different portrayals:

a. The genomics, description of the 〈life〉 build-up and evolution by biology of matter;

b. The memonics, account of the (intelligences start and fruition by cognition of spirit.

The genomics is actively developed by the molecular biology. The memonics shall yet be invented. The three communication, trade and legality ranges (Figure 3), are multi-facet opportunities, enabled by minds, yet, maybe, pre-set in brains. But: why orangtangs and men differ from gene evolution, to meme fruition? The communication ranges are impressive: we have many languages, showing independence of «closed unions to specialise the teaching/ learning children phases. Do the living beings have multiple brain pre-settings? The trade and legality ranges, mostly, entail (private> vs. 〈public〉 effects. Does mimicking privilege political or economic authority, and do «social breakthroughs» reveal differences in brain's architectures? Absolute truths are thought haughty, because a priori sets need faith, unless proofs are detected. In default of hard marks, the contingency has plausibility, with thrifty cues in the interpersonal agreed verdicts.

\section{Acknowledgements}

None.

\section{Conflict of interest}

The author declares there is no conflict of interest in this work.

\section{References}

1. Baggott J. Farewell to reality: how modern physics has betrayed the search for scientific truth. London; 2013.

2. Orbecchi M. Biologia dell'anima: teoria dell'evoluzione e paleoterapia. Torino: Boringhieri; 2015.

3. Schmidt E, Cohen J. The digital age: reshaping the future of people, nations and business. New York: Knopf; 2013.

4. Tononi G, Sporns O. Selectionism and the brain. San Diego: Academic Press; 1994.

5. Agar J. Science in the twentieth century and beyond. London; 2012.

6. Davies N. Vanished kingdoms: the rise and fall of states and nations. New York; 2012

7. Pearl J. Causality: models, reasoning and inference. Cambridge: Cambridge University Press; 2000.

8. Sussman R. The biological basis for human behaviour. Simon and Schuster Custom Pub. Ne; 1997.

9. Vallortigara G, Panciera N. Cervelli che contano. Milano: Adelphi; 2014.

10. Barrow GD. The book of universes. London: Bodley Head; 2011.

11. Cox B, Forshow J. The quantum universe: everything that can happen does happen. New York: Capo Press; 2012. 
12. Henshaw JM. A tour of the senses: how the brain interprets the world. Baltimor: Johns Hopkins University Press; 2012.

13. Kaku M. Physics of the future: how science will shape human destiny and daily lives by year 2100. London: Allen Lane; 2011.

14. Päs H. The perfect wave: with neutrinos at the boundary of space and time. Cambridge: Harvard University Press; 2014.

15. Attali J. Une brève histoire de l'avenir. Paris: Fayard; 2006.

16. Michelini RC. Robot age knowledge changeover. New York: Nova Sci Pub; 2009.

17. Wallace DF. Date, time and language: an essay on free will. New York: Columbia University Press; 2010.

18. Zhe HD. The physical basis of the direction of time. Berlin: Springer Verlag; 1989.

19. Babacan H, Herrmann P. Nation state and ethnic diversity. New York: Nova Sci. Pub; 2012.

20. Green B. The hidden reality: parallel universes and the deep laws of the cosmos. London: Penguin Books; 2012.

21. Jha PS. The twilights of the nation states. London: Pluto Press; 2006

22. Mithen S. The prehistory of the mind: the cognitive origins of arts, religion and science. Thames \& Hudson; 1996.

23. Thye R, Lawler EJ. Altruism and pro-social behaviour in groups. Bingley: Emerald Book; 2009.

24. Warsh D. Knowledge and the wealth of nations: a story of economic discovery. New York: WW. Norton; 2006.

25. Close F. The infinity puzzle: quantum field theory and the hunt for an orderly universe. New York: Basic Book; 2012.

26. Flynn JR. What is intelligence? Beyond the Flynn effect. New York: Cambridge University Press; 2009.

27. Hobson P. The cradle of thought: exploring the origin of thinking. New York: Oxford University Press; 2004.

28. Michelini RC. Knowledge society engineering: a sustainable growth pledge. New York: Nova Science Pub; 2011.

29. Rowlands M. The science of the mind: from extended mind to embodied phenomenology. Cambridge: MIT Press; 2010.

30. Dennet D. Intuition pumps and other tools for thinking. London: WW Norton; 2013.

31. Huemer M. The political authority: examination of the right of coerce and the duty of obey. London: Palgrave MacMillan; 2013.

32. Manna F. A peculiarity of the human species: the language of symbols. Isernia: Cicchetti; 2006

33. Piattelli Palmarini M, Fodor J. What Darwin got wrong. London: Profile Books; 2011

34. Ryder R. Natural selection and the emergence of mind. London: DavisPoynter; 1975.

35. Sternberg RJ. Cognitive psychology. Belmont: Wadsworth; 2009

36. Viale R. Methodological cognitivism: cognition, science and innovation. Berlin: Springer; 2014.

37. Campbell T. My big ToE: the theory of everything. New York: Lightning Strike Books; 2007

38. Lincoln D. Understanding the universe: from quarks to the cosmos. London: World Sci. Books; 2012.
39. Smolin L. Time reborn: from the crisis of physics to the future of the universe. London: Allen Lane; 2013.

40. Turok N. The universe within: from quantum to cosmos. London: Faber \& Faber; 2013.

41. Wilbur K. A brief history of everything. Boston 1l: Shambhala; 1996.

42. Bellone E. Something out there: how the brain creates reality. Torino: Codice Edizioni; 2011

43. Michelini RC. Society progress evolution: sustainability and responsiveness. New York: Nova Science Pub; 2012.

44. Pennisi A, Falzone A. Il prezzo del linguaggio: evoluzione ed estinzione nelle scienze cognitive. Bologna: Il Mulino; 2010.

45. Rovelli C. Reality is not as it appears to us. Milano: Raffaello Cortina; 2014.

46. Sammicheli L, Lavazza A. The crime of the brain. Torino: Codice Edizione; 2012

47. Bateson W. Problems of genetics. New Haven: Yale University Press; 2013.

48. Craighero L. Neuroni a specchio. Bologna: Il Mulino; 2010.

49. McEtheny V. Drawing the map of life: inside the human genome project. New York: Basic Books; 2010.

50. Ridley M. Genome: the autobiography of a species in 23 chapters. London: Fourth Estate; 1999.

51. Flynn JR. Intelligence and human progress: the story of what was hidden in our genes. Amsterdam: Academic Press; 2013.

52. Gazzaniga M. Who's in charge? Free-will and the science of the brain London: Constable \& Robinson; 2012.

53. Michelini RC. Cognitive revolution quest: human civilisation prospects. Roma; Aracne; 2016.

54. Noë A. Out of our heads, why you are not your brain. New York: Hills \& Wang; 2009.

55. Schwartz JM, Begley S. The mind and the brain: neuroplasticity and the power of mental force. New York: ReganBooks; 2002.

56. Balaguer M. Free will. Cambridge: MIT Press; 2014.

57. Eccles JC. Evolution of the brain and creation of consciousness. Paris: Editions Flammarion; 1989

58. Mullah S. The selfs and its shadows. Oxford: Oxford Uni Press; 2013.

59. Nagel T. Mind \& cosmos: why Neo-Darwinism conception of nature is almost surely false. New York: Oxford Uni. Press; 2012.

60. Sorrentino F, Pettenati MC. Horizons of knowledge. Firenze: Firenze University Press; 2014.

61. Tomasello M. The origins of human communication. Milan: Raffaello Cortina Editore; 2008.

62. Hughes TP. Human built world: how to think about technology and culture. Chicago: Univ. Chicago Press; 2004.

63. Legrenzi P. First lesson in cognitive science. Bari: Laterza; 2011.

64. Michelini RC, Razzoli RP. Reliability and safety of the industrial product Milano: Tecniche Nuove; 2000.

65. Piattelli Palmarini M. Who do we think we are? Milano: Mondadori; 2012.

66. Shermer M. The moral arc: how science and reason lead humanity to truth, justice and freedom. New York: Harry Holt; 2015. 
67. Wilkinson R, Picket K. The sprit level: why more equal societies almost always do better. London: Allen Lane; 2009.

68. Fasolo A. The theory of evolution and its impact. Milano: Springer Italia; 2012.

69. Lane N. The vital question: why is life the way it is? London: Profile; 2015 .

70. Nelkin D, Lindee MS. The DNA mystique: the gene as cultural icon. New York: Freeman; 1995.

71. Rose S. Lifelines, biology, freedom, determinism. London: Allen Lane; 1997.

72. Wheeler M. Extended X: recarving the biological and cognitive joints of nature. Cambridge: MIT Press; 2011.

73. Damasio A. Self comes to mind: constructing the conscious brain. London: Heinemann; 2011.

74. Holt J. Why does the world exist? An essential detective story. London: Norton; 2012.

75. Lieberman DE. The evolution of the human head. Cambridge: Harvard Uni. Press; 2012.

76. Menary R, editors. The extended mind. Cambridge: MIT Press: 2011.

77. Sennett R. Together: rituals, pleasures and politics of cooperation. London: Allen Lane; 2012.

78. Changeux JP. The Good, the true and the beautiful: a neuronal approach. New Hav: Yale Uni. Press; 2013.

79. Michelini RC. Knowledge entrepreneurship and sustainable growth. New York: Nova Sci. Pub; 2008.
80. Newberg A, D'Aquili A, Rause V. Why God won't go away: brain science \& biology of belief. New York: Ballantine Books; 2001.

81. Siegel DJ. Pocket guide to interpersonal neurobiology: integrative handbook of mind. New York: Mind Your Brain Inc; 2012.

82. Yau ST, Nadis S. The shape of inner space: string theory \& hidden dimension geometry. New York: Basic Books; 2010.

83. Lackey J. Learning from words: testimony as source of knowledge. Oxford: Oxford Uni. Press; 2009.

84. Pievani T. Unexpected life. Milano: Cortina Ed; 2011.

85. Wegner DM. The illusion of conscious will. Cambridge: Bradford Books; 2002 .

86. Marcel A, Bermudez JL, Eilan N, editors. The body and the self. Cambridge: MIT Press; 2001.

87. Robinson JA, Acemoglu D. Why nations fall: the origin of power, prosperity and poverty. New York: Crown Pub; 2012.

88. Stewart J, Grapenne O, DiPaolo E, editors. Reflections on the bodily basis of consciousness. Cambridge: MIT Press; 2008.

89. Thompson E. Mind and life. Cambridge: Harvard Uni. Press; 2007.

90. Vince G. Adventures in the Anthropocene: a journey to the heart of the planet we made. London: Chatto \& Windus; 2014.

91. Whitman J. The fundamentals of global governance. Basingstoke: MacMillan; 2009. 